\title{
Protein kinase antagonists inhibit invasion of mammalian cells by Fonsecaea pedrosoi
}

\author{
Cristiana L. Limongi, ${ }^{1}$ Wanderley De Souza ${ }^{2}$ and Sonia Rozental ${ }^{1}$
}

\begin{abstract}
Correspondence
Sonia Rozental

rozental@biof.ufr.jbr
\end{abstract}

Received 15 April 2002

Accepted 15 November 2002

\begin{abstract}
Laboratório de Biologia Celular de Fungos ${ }^{1}$ and Laboratório de Ultraestrutura Celular Hertha Meyer ${ }^{2}$, Instituto de Biofísica Carlos Chagas Filho, Universidade Federal do Rio de Janeiro, Rio de Janeiro, RJ, Brazil
\end{abstract}

The phosphorylation process is an important mechanism of cell signalling and regulation. It has been implicated recently in defence strategies against a variety of pathogens that alter host signalling pathways in order to facilitate their invasion and survival within host cells. In this study, the involvement of protein kinases (PKs) has been investigated in attachment and invasion by the pathogenic fungus Fonsecaea pedrosoi within epithelial cells and macrophages. The use of the PK inhibitors staurosporine, genistein and calphostin $\mathrm{C}$ prior to infection provided significant information about the role played by PKs in the F. pedrosoi-host cell interaction. All three PK inhibitors could reduce cell invasion by $F$. pedrosoi significantly. Pre-treatment of macrophages, epithelial cells or conidia with PK inhibitors decreased fungus invasion, and this effect could be overcome by okadaic acid, a phosphatase inhibitor. Immunofluorescence assays showed that tyrosine residues were phosphorylated in the first step of the interaction, while serine residues were phosphorylated in the subsequent step of entry of the parasite into the host cell. These results suggest that both host-cell and conidium PK activities are important in the interaction process, playing a significant role in cell invasion.

\section{INTRODUCTION}

Several studies have shown that micro-organisms have developed the ability to interact with host-cell receptor molecules to induce their own internalization (Moulder, 1985; Falkow, 1991; Isberg, 1991; Pace et al., 1993; Káposzta et al., 1999). Entry of the pathogen into the host cell is initiated by binding to its surface, which is followed by internalization. These events allow a pathogen to sequester itself within a particular organ site or to gain access to deeper tissues. Both host and pathogen encode factors that determine which type of host cells will be infected. Factors that determine whether the micro-organism will remain surfacebound or be internalized include: (i) the nature of the hostcell receptors, (ii) the strength of the physical interaction that occurs between the host and microbial ligands and (iii) whether the micro-organisms trigger signals that either stimulate or antagonize internalization (Isberg \& Tran Van Nhieu, 1994). Host-cell actin filaments facilitate the internalization step, since agents that disrupt actin filaments, such as cytochalasin $\mathrm{D}$, inhibit internalization of most pathogens

Abbreviations: $\mathrm{Al}$, adhesion index; $\mathrm{El}$, endocytic index; $\mathrm{PK}$, protein kinase; $\mathrm{PKC}, \mathrm{Ca}^{2+}$ /phospholipid-dependent protein kinase; PTK, protein tyrosine kinase.

Immunofluorescence micrographs of the interaction between F. pedrosoi conidia and IC21 macrophages are available as supplementary material in JMM Online (http://jmm.sgmjournals.org).
(Clerc \& Sansonetti, 1987; Finlay \& Falkow, 1988; Finlay et al., 1989; Farbiarz et al., 1992; Rosenshine et al., 1992). Given the active involvement of the host cytoskeleton, it appears that invasive pathogens generate an 'uptake signal' that induces the host cell to internalize them (Rosenshine et al., 1992). It is clear that binding of the parasite to the hostcell surface is not necessarily followed by internalization, as many parasites bind to the cell surface but do not enter the cell. These observations suggest that, following parasite attachment, this 'uptake signal' must be generated in order for internalization to take place (Vieira et al., 1994).

Cell-mediated immunity ( $\mathrm{T}$ cells) and non-specific cellular immunity (e.g. macrophages, natural killer cells and neutrophils) are generally believed to provide the main defence mechanisms against fungi. The importance of cellular defence mechanisms for protection against fungi is supported by the clinical observation that most invasive fungal infections occur in individuals with defective cellular immunity (Levitz, 1992; Casadevall, 1995).

The human pathogen Fonsecaea pedrosoi is one of the aetiological agents of chromoblastomycosis, a subcutaneous disease that shows no major tendency to disseminate to deeper organs (McGinnis, 1983; Rippon, 1988). All agents of subcutaneous mycosis induce the influx of cells belonging to the mononuclear phagocytic system, producing a granulomatous reaction. In tissues, conidia and sclerotic cells of $F$. 
pedrosoi can be detected within macrophages and neutrophils as well as extracellularly. Previous studies have demonstrated that resident macrophages have no fungicidal or fungistatic activity against $F$. pedrosoi and that, $24 \mathrm{~h}$ after the beginning of the interaction, the macrophages are completely destroyed by the fungi (Farbiarz et al., 1990; Rozental et al., 1994). Different cell types have been used to study the $F$. pedrosoi-host cell interaction, showing that this fungus can invade epithelial cells like Chinese hamster ovary $(\mathrm{CHO})$ cells (Limongi et al., 1997), Madine-Darby canine kidney cells and also cytochalasin-treated macrophages (Farbiarz et al., 1992). These results suggest that $F$. pedrosoi might penetrate host non-phagocytic cells through an active process. We demonstrated recently that the interaction of $F$. pedrosoi conidia with mannose and $\mathrm{N}$-acetylglucosamine surface carbohydrates in $\mathrm{CHO}$ epithelial cells is mediated by a $50 \mathrm{kDa}$ lectin-like protein found in the conidium cell wall (Limongi et al., 2001).

In eukaryotes, phosphorylation/dephosphorylation cycles represent a major mechanism for switching cellular pathways in response to changing circumstances, both internal developmental cues and external environmental stimuli (Dickman \& Yarden, 1999). Different classes of protein kinases (PKs) play a major role in transducing extracellular signals and regulating essential cellular processes in mammalian cells, such as cell growth, differentiation, transcription, disease and death (Courtneidge, 1994; Jarvis et al., 1994; Van der Geer et al., 1994; Hunter, 1995; Dickman \& Yarden, 1999). The phosphorylation process has recently been implicated in defence strategies against a variety of pathogens that have evolved mechanisms to alter host-signalling pathways in order to facilitate their invasion and survival within host cells. We have investigated the involvement of PKs in the attachment to and invasion of CHO epithelial cells and IC21 macrophages by $F$. pedrosoi. We examined the involvement of these enzymes present in host cells and in the fungal cell in transducing signals needed for conidium internalization by epithelial cells and macrophages. The use of the PK inhibitors staurosporine, genistein and calphostin C prior to infection gave us significant information about the role played by PKs in the $F$. pedrosoi-host cell interaction. In this paper, we present evidence that $\mathrm{PK}$ inhibitors can significantly reduce invasion by F. pedrosoi.

\section{METHODS}

Micro-organisms. A pathogenic strain of $F$. pedrosoi was isolated from a human case of chromoblastomycosis (Oliveira et al., 1973). Stock cultures were maintained on Sabouraud's glucose agar under mineral oil and kept at $4{ }^{\circ} \mathrm{C}$. Transfers were made every 6 months. Conidia were obtained from the stock culture and incubated at $28^{\circ} \mathrm{C}$ for 5 days in Czapek-Dox medium, under shaking conditions. The cultures were then filtered in a $40-60 \mathrm{G}$ porous plate filter; mycelial forms were retained whereas conidia passed through the filter. Cells were then recovered by centrifugation $\left(13600 \mathrm{~g}, 30 \mathrm{~min}, 4^{\circ} \mathrm{C}\right)$.

Mammalian cell cultivation. $\mathrm{CHO}$ parental cell line $\mathrm{Pro}^{-5}$ was purchased from the ATCC (61-CCL). The cells were grown in minimum essential alpha medium (MEAM; Gibco), supplemented with $10 \%$ fetal bovine serum (FBS; Gibco), at $37^{\circ} \mathrm{C}$ with $5 \% \mathrm{CO}_{2}$, until they reached confluence. They were subcultured at least once a week. IC21 macrophage cells were also purchased from the ATCC (TIB-186). The cells were grown in RPMI medium supplemented with sodium pyruvate $\left(0 \cdot 11 \mathrm{~g} \mathrm{l}^{-1}\right)$, myo-inositol $\left(0.0072 \mathrm{~g} \mathrm{l}^{-1}\right)$, glucose $\left(4.5 \mathrm{~g} \mathrm{l}^{-1}\right)$ and $10 \%$ FBS, at $37{ }^{\circ} \mathrm{C}$ with $5 \% \mathrm{CO}_{2}$. They were subcultured at least once a week. Prior to the interaction with the fungus, $\mathrm{CHO}$ cells and IC21 macrophages were plated onto 24-well multidishes in the presence of FBS and incubated at $37^{\circ} \mathrm{C}$ for $24 \mathrm{~h}$. After this time, the cells were washed in MEAM or RPMI and counted in an inverted phase-contrast microscope.

PK inhibitors. Genistein (4',5,7-trihydroxyisoflavone), a proteintyrosine kinase (PTK) inhibitor; staurosporine (antibiotic AM-2282 from Streptomyces sp.), a broad-range kinase inhibitor, calphostin C (UCN-1028c, from Cladosporium cladosporioides), a $\mathrm{Ca}^{2+} /$ phospholipid-dependent PK (PKC) inhibitor, and okadaic acid, a phosphatase inhibitor (Tamaoki, 1991), were purchased from Sigma. Stock solutions were made in $100 \%$ DMSO and stored at $-20{ }^{\circ} \mathrm{C}$ until use. DMSO did not affect cultures at the final concentration used $(0 \cdot 01 \%)$. Prior to use, the inhibitors were diluted in MEAM or RPMI and the mixture was added to the mammalian cells or to the conidia. The final concentrations used in the assays were: staurosporine, $0.5,1.0$ and $2.0 \mu \mathrm{M}$; genistein, 50, 100 and $200 \mu \mathrm{M}$; calphostin C, 25, 50 and $100 \mathrm{nM}$; and okadaic acid, 5, 10 and $20 \mathrm{nM}$.

Host cell-F. pedrosoi interaction. $\mathrm{CHO}$ epithelial cells and IC21 macrophages were incubated for $30 \mathrm{~min}$ at $37^{\circ} \mathrm{C}$ in the presence of $0.01 \%$ DMSO, $0 \cdot 5,1.0$ or $2 \cdot 0 \mu \mathrm{M}$ staurosporine, 50,100 or $200 \mu \mathrm{M}$ genistein or 25, 50 or $100 \mathrm{nM}$ calphostin $\mathrm{C}$, washed three times and allowed to interact with $F$. pedrosoi conidia for $1 \mathrm{~h}$ at $37^{\circ} \mathrm{C}, 5 \% \mathrm{CO}_{2}$. The conidium : host cell ratio was adjusted to $10: 1$ by counting the number of conidia with a Neubauer chamber (Sigma). Alternatively, after PK inhibitor treatment, the cells were re-incubated in the presence of 5,10 or $20 \mathrm{nM}$ okadaic acid, for $30 \mathrm{~min}$, before the interaction. In other assays, the conidia were incubated with the same PK inhibitors at the same concentrations, washed and allowed to interact with nontreated CHO cells and IC2 1 macrophages for $1 \mathrm{~h}$, at $37{ }^{\circ} \mathrm{C}, 5 \% \mathrm{CO}_{2}$ and, alternatively, were also re-incubated with okadaic acid prior the interaction. After the interaction, the cultures were rinsed three times in MEAM or RPMI to remove free conidia, fixed in Bouin's solution and stained with Giemsa (Merck). Bouin's solution was made in-house and contains $375 \mathrm{ml}$ saturated aqueous picric acid (Merck), $125 \mathrm{ml}$ stock formaldehyde $(37 \%, \mathrm{w} / \mathrm{w})$ (Reagen) and $25 \mathrm{ml}$ glacial acetic acid (Reagen). The percentage of infected cells was determined by randomly counting a minimum of 300 cells on each duplicated cover slip and experiments were repeated at least three times. The adhesion index (AI) was calculated by multiplying the mean number of attached conidia per $\mathrm{CHO}$ cell by the percentage of infected cells observed by microscopic examination using the immersion objective of a Zeiss Universal photomicroscope. The endocytic index (EI) was determined the same way, but was based on the mean number of ingested conidia.

Transmission electron microscopy. After the interaction, performed in $25 \mathrm{~cm}^{2}$ flasks, the cultures were fixed for $1 \mathrm{~h}$ at room temperature with a solution containing $1 \%$ glutaraldehyde, $4 \%$ paraformaldehyde and 1 $\mathrm{mM} \mathrm{CaCl}_{2}$ in $0 \cdot 1 \mathrm{M}$ cacodylate buffer, $\mathrm{pH} 7 \cdot 2$. The cells were then gently scraped off with a rubber policeman, washed with the same buffer and post-fixed for $1 \mathrm{~h}$ in a solution containing $1 \% \mathrm{OsO}_{4}, 0 \cdot 8 \%$ potassium ferricyanide and $1 \mathrm{mM} \mathrm{CaCl}_{2}$ in a cacodylate buffer, $\mathrm{pH} 7 \cdot 2$. Subsequently, the cells were rinsed, dehydrated in acetone and embedded in Epon. Ultrathin sections were stained with uranyl acetate and lead citrate and observed with a Zeiss 900 electron microscope.

Immunofluorescence microscopy. F. pedrosoi conidia and IC21 macrophages were allowed to interact for $30 \mathrm{~min}$ as described above, 
washed three times with $1 \mathrm{mM}$ sodium vanadate in PHEM buffer (60 $\mathrm{mM}$ PIPES-NaOH, 20mM HEPES- $\mathrm{NaOH}, 10 \mathrm{mM}$ EGTA, $5 \mathrm{mM}$ $\mathrm{MgCl}_{2}, 70 \mathrm{mM} \mathrm{KCl}, \mathrm{pH} 7 \cdot 2$ ) and fixed with freshly prepared $4 \%$ formaldehyde in $0 \cdot 1 \mathrm{M}$ phosphate buffer. Cells were permeabilized with $0 \cdot 1 \%$ Triton X-100 in PHEM buffer for $90 \mathrm{~s}$ and then treated with a blocking solution containing $50 \mathrm{mM}$ ammonium chloride and $1.5 \%$ BSA for $120 \mathrm{~min}$ at room temperature. The samples were then incubated for $60 \mathrm{~min}$ in the presence of phalloidin-rhodamine (diluted $1: 100$ ), washed and then incubated in the presence of mAbs recognizing phosphotyrosine, phosphoserine or phosphothreonine residues (diluted $1: 20$ in PBS), washed three times in PBS/3\% BSA and incubated for $60 \mathrm{~min}$ in the presence of FITC-labelled goat anti-mouse IgG (diluted 1:100 in PBS). The cover slips were then washed in PBS and mounted in slides with anti-fade (Molecular Probes) and observed in a Zeiss confocal laser scanning microscope.

\section{RESULTS}

\section{Effect on cell adhesion of previous treatment of host cells with PK inhibitors}

Staurosporine treatment decreased binding of conidia to IC21 macrophages (Fig. 1a). At $2 \cdot 0 \mu \mathrm{M}$ staurosporine, treatment of IC21 macrophages prior to infection reduced the AI by $77 \%$. However, no significant effect on the AI was observed for Pro ${ }^{-5}$ (Fig. 1b). The cells were washed extensively before interactions to avoid possible direct effects of PK inhibitors upon conidia. Genistein also inhibited conidium attachment to IC21 macrophages, with a reduction of the AI
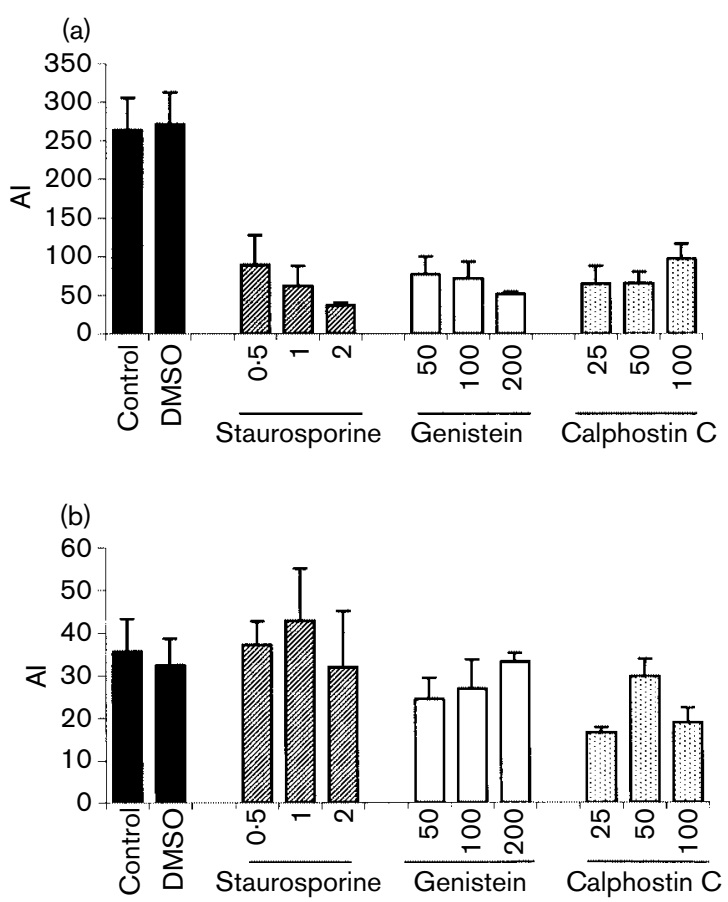

Fig. 1. Effect of pre-treatment of host cells with $\mathrm{PK}$ inhibitors for 30 min at $37^{\circ} \mathrm{C}$ on the $\mathrm{Al}$ for the interaction of $F$. pedrosoi conidia for $1 \mathrm{~h}$ at $37^{\circ} \mathrm{C}$ with IC21 cells (a) and parental $\mathrm{Pro}^{-5} \mathrm{CHO}$ cells (b). PK concentrations are indicated in $\mu \mathrm{M}$ (genistein and staurosporine) or $\mathrm{nM}$ (calphostin C). by $68 \%$ when used at a concentration of $200 \mu \mathrm{M}$. Genistein did not interfere with the attachment of the fungus to Pro $^{-5}$ (Fig. 1b), as seen for staurosporine. Previous treatment of the cells with calphostin $\mathrm{C}$ reduced the AI to IC21 macrophages by $41 \%$ (Fig. 1a) and to Pro ${ }^{-5}$ by $47 \%$ (Fig. 1b). We decided to use a period of $1 \mathrm{~h}$ for binding; we have previously used $2 \mathrm{~h}$ and found that the values were very similar (Limongi et al., 1997, 2001). Previous observations of our group have shown that prolonged incubation of infected mammalian cells allows both ingested fungi, as well as fungi that remain attached to the macrophage surface, to differentiate into hyphae, since resident macrophages have little or no cytotoxic effect in vitro on F. pedrosoi (Farbiarz et al., 1990). On the other hand, when we tested times shorter than $1 \mathrm{~h}$, fungi were not observed inside epithelial cells, probably because they are non-professional phagocytic cells (data not shown).

\section{Effect on fungus internalization of previous treatment of host cells with PK inhibitors}

In a previous work, we demonstrated that, by light microscopy of Giemsa-stained preparations of interaction assays, we can distinguish between attached or ingested fungi, since the ingested fungi are located within well-stained membranebound vacuoles in mammalian cells (Limongi et al., 1997). Our results show that, when used at a concentration of $2 \mu \mathrm{M}$, staurosporine decreased conidia internalization by IC2 1 macrophages (Fig. 2a) and CHO cells (Fig. 2b) by 78 and $73 \%$, respectively. Genistein also inhibited conidia phagocytosis by IC21 macrophages, by $77 \%$ (Fig. 2a). In addition, previous incubation of the epithelial cells with genistein led to a remarkable decrease of the EI, by $52 \%$ (Fig. 2b). Previous
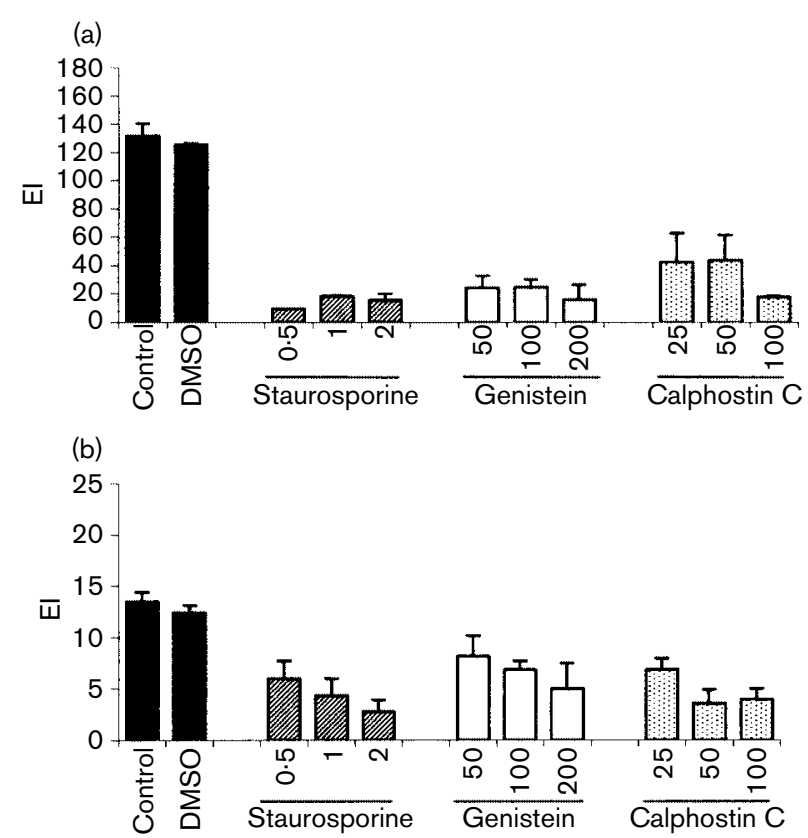

Fig. 2. Effect of pre-treatment of host cells with PK inhibitors for 30 min at $37^{\circ} \mathrm{C}$ on the El for the interaction of F. pedrosoi conidia for $1 \mathrm{~h}$ at $37^{\circ} \mathrm{C}$ with IC21 cells (a) or parental $\mathrm{PrO}^{-5} \mathrm{CHO}$ cells (b). 
treatment of macrophages with calphostin C decreased the EI by $75 \%$ (Fig. 2a) and also inhibited internalization of the fungi by epithelial cells (Fig. 2b). These drug effects were not dose-dependent. However, in most of the cases, the higher dose was the one that led to the greater inhibitory effect.

\section{Effect on cell adhesion of previous treatment of the fungus with PK inhibitors}

Previous incubation of $F$. pedrosoi conidia with staurosporine, genistein or calphostin $\mathrm{C}$ did not interfere significantly with their adhesion to IC21 macrophages (Fig. 3a). On the other hand, previous incubation with staurosporine decreased the AI to epithelial cells by almost $37 \%$. At $200 \mu \mathrm{M}$, genistein treatment caused a decrease of $50 \%$ in adhesion of the fungus to these cells (Fig. 3b). Treatment with $100 \mathrm{nM}$ calphostin $\mathrm{C}$ caused the most significant effect on epithelial cells, with a reduction of $63 \%$ in the AI (Fig. 3b). Conidium viability after $\mathrm{PK}$ inhibitor treatment was greater than $90 \%$, as determined by staining with $0 \cdot 04 \%$ Trypan blue (J. T. Baker Chemical Co.). As a control, conidia were not incubated with the PK inhibitors prior to the interaction. Conidium incubation with DMSO only prior to the interaction was used as a second control.

\section{Effect on fungus internalization of previous treatment of the fungus with PK inhibitors}

Previous incubation of the fungus with staurosporine, genistein or calphostin $\mathrm{C}$ did not interfere with its entry into
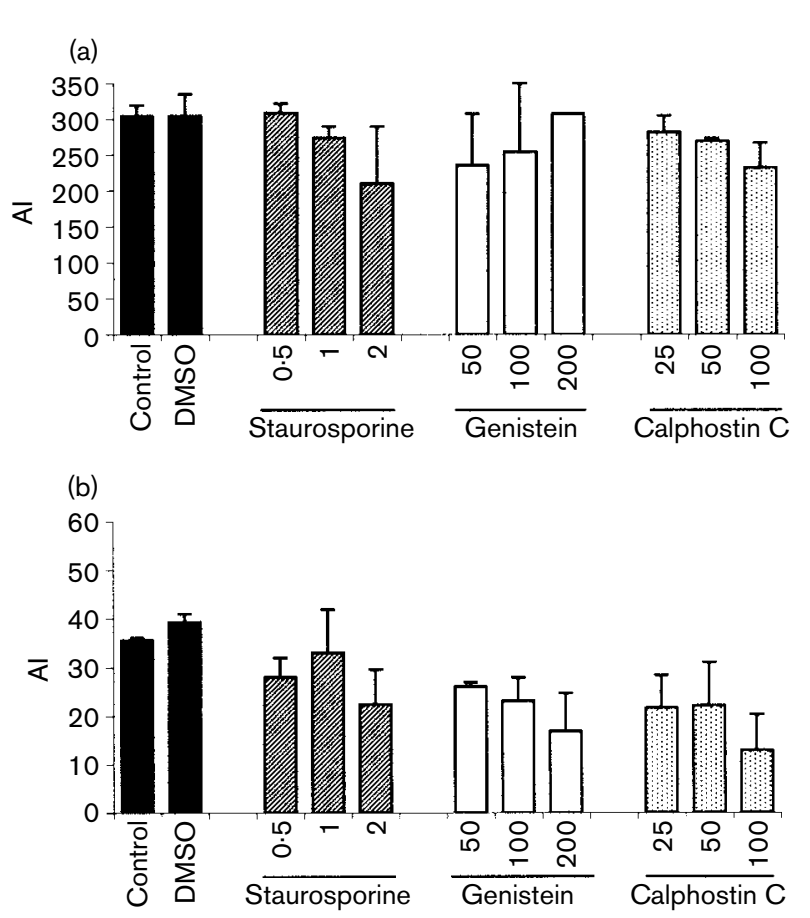

Fig. 3. Effect of pre-treatment of conidia with $\mathrm{PK}$ inhibitors for $30 \mathrm{~min}$ at $37^{\circ} \mathrm{C}$ on the Al after an interaction of $1 \mathrm{~h}$ at $37^{\circ} \mathrm{C}$ with IC2 1 cells (a) or parental $\mathrm{Pro}^{-5} \mathrm{CHO}$ cells (b).
IC21 macrophages (Fig. 4a). On the other hand, all the PK antagonists used markedly reduced the EI for $\mathrm{CHO}$ cells. Staurosporine and genistein treatment inhibited the EI by about $50 \%$ (Fig. 4b). Once again, $100 \mathrm{nM}$ calphostin C caused the greatest reduction of the EI on epithelial cells, reaching $70 \%$ (Fig. 4b).

\section{Antagonism by okadaic acid of the effect of PK inhibitors on the interaction of mammalian cells with conidia}

Staurosporine, genistein and calphostin C are widely used as inhibitors of PKs (Tamaoki, 1991). However, as with any inhibitor, it is difficult to prove that the inhibition of attachment and invasion by these drugs results from an effect on protein phosphorylation rather than on some other, uncharacterized target (Ward et al., 1994). To address this issue, we attempted to overcome the effects of PK inhibitors with okadaic acid, a specific inhibitor of protein phosphatases 1 and 2A (Cohen et al., 1990; Hardie et al., 1991). We found that the addition of okadaic acid after treatment of cells with PK inhibitors could indeed partially alleviate the inhibitory effect of the drugs on the cells (Fig. 5). In most experiments, okadaic acid did not stimulate invasion by itself. The extent of recovery observed varied according to cell type. In macrophages, addition of okadaic acid completely reversed the effect of PK inhibitors on the EI (Fig. 5a). In epithelial cells, almost total reversal was also observed for all the drugs used (Fig. 5b). This reversion effect occurred in a
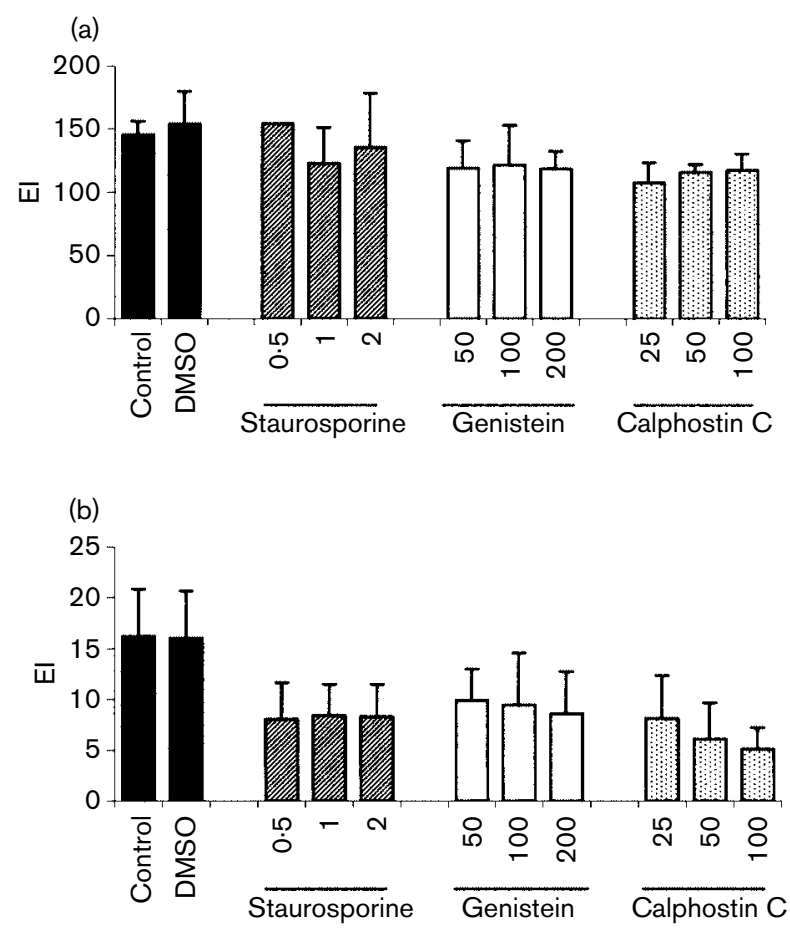

Fig. 4. Effect of pre-treatment of conidia with $P K$ inhibitors for 30 min at $37{ }^{\circ} \mathrm{C}$ on the El after an interaction of $1 \mathrm{~h}$ at $37^{\circ} \mathrm{C}$ with IC21 cells (a) or parental $\mathrm{PrO}^{-5} \mathrm{CHO}$ cells (b). 

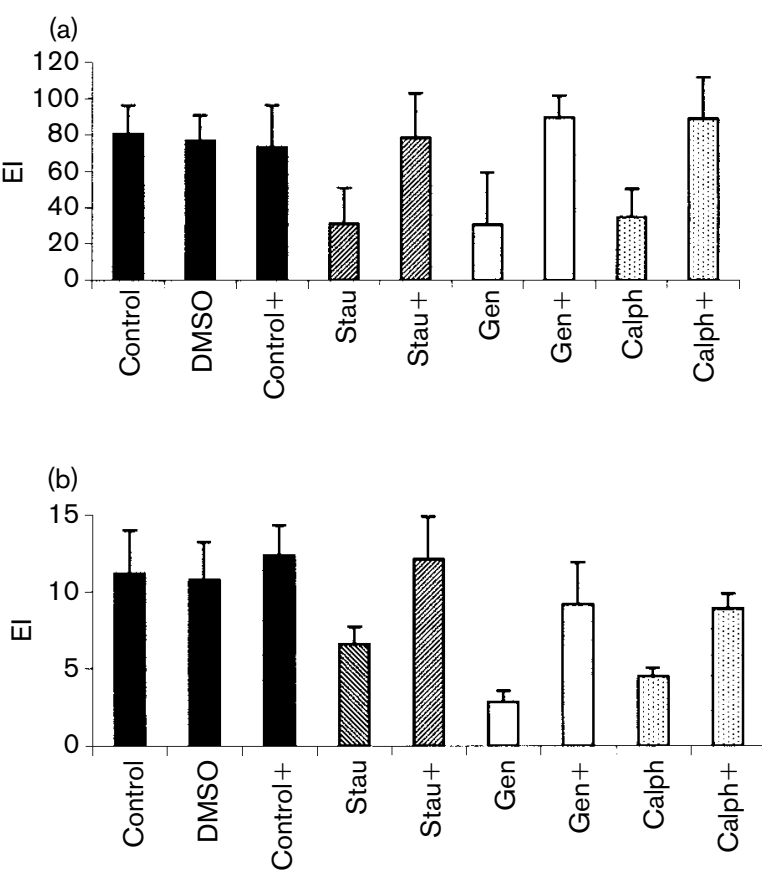

Fig. 5. Influence of incubation with okadaic acid for $30 \mathrm{~min}$ at $37^{\circ} \mathrm{C}$ after pre-treatment of IC21 cells (a) or parental Pro ${ }^{-5} \mathrm{CHO}$ cells (b) with PK inhibitors for 30 min at $37^{\circ} \mathrm{C}$ on the interaction with conidia of F. pedrosoi for $1 \mathrm{~h}$ at $37^{\circ} \mathrm{C}$. +, Okadaic acid added at $20 \mathrm{nM}$; DMSO, DMSO only; Gen, $200 \mu \mathrm{M}$ genistein; Stau, 2.0 $\mu \mathrm{M}$ staurosporine; Calph, $100 \mathrm{nM}$ calphostin C.

dose-dependent manner, as shown for staurosporine (Fig. 6). The same reversible behaviour was observed for both genistein and calphostin C (data not shown).

\section{Antagonism of the effect of PK inhibitors on the fungus by okadaic acid}

Incubation of conidia with $\mathrm{PK}$ inhibitors prior to the interaction in the presence of okadaic acid did not interfere with the interaction with macrophages. In contrast, when epithelial cells were used, the effects of PK inhibitors were partially reversed by okadaic acid; however, this effect was not evident for genistein (data not shown).

\section{Immunofluorescence microscopy}

We attempted to localize phosphotyrosine, phosphoserine, phosphothreonine residues and the actin cytoskeleton during the conidium-IC21 macrophage interaction using immunofluorescence techniques. Labelling with anti-phosphotyrosine antibodies was very intense on the macrophage surface, especially in those that were in contact with the fungus. Immunofluorescence micrographs are available as supplementary material in JMM Online (http://jmm. sgmjournals.org). Actin filaments, revealed using phalloidin-rhodamine, were concentrated at the regions of binding of conidia to cells, co-localizing with phosphotyrosine domains. Anti-phosphoserine antibody labelling was re-
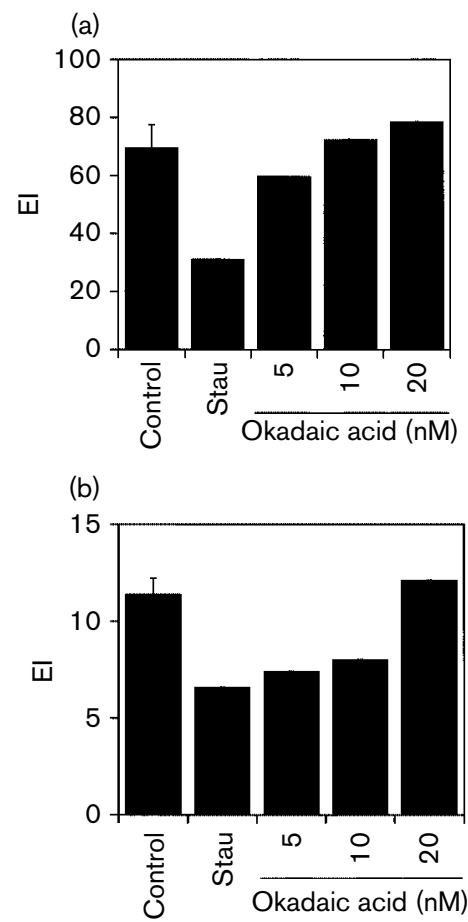

Fig. 6. Alleviation by okadaic acid at concentrations of 5,10 or $20 \mathrm{nM}$ of the effect of $2.0 \mu \mathrm{M}$ staurosporine (Stau) on the interaction of $F$. pedrosoi with IC21 macrophages (a) and parental Pro $^{-5} \mathrm{CHO}$ cells (b).

stricted to endocytic vacuoles containing conidia. No significant labelling of the cells was observed using antiphosphothreonine antibodies, except for some conidia located inside macrophages.

\section{Transmission electron microscopy of the interaction of $\boldsymbol{F}$. pedrosoi conidia with host cells}

Transmission electron micrographs of the interaction of conidia with macrophages showed emission of pseudopods as an initial step of conidium internalization (data not shown) and conidia inside a 'tight' phagosome, where the membrane of the vacuole was apposed directly over the fungal cell wall (Fig. 7a). When cells pre-treated with PK inhibitors were allowed to interact with the fungus, ingested conidia were observed inside a 'loose'-type phagosome (Fig. $7 b-d)$, with a wide space between the vacuole membrane and the fungal cell wall, similar to those observed in epithelial cells (Fig. 7e, f). In cells treated with staurosporine, the host membrane seemed to lose its natural shape and showed projections all over the surface (Fig. $7 \mathrm{~b}$ ). Pre-treatment with genistein (Fig. 7c) and calphostin C (Fig. 7d) also affected membrane continuity, showing disruptions and the presence of a significant number of vacuoles located near the phagosomes. The interaction of $F$. pedrosoi with epithelial cells showed that the ingested conidia are located inside a 'loose'type phagosome (Fig. 7e, f). When epithelial cells were pretreated with calphostin, the host membrane seemed to lose its 


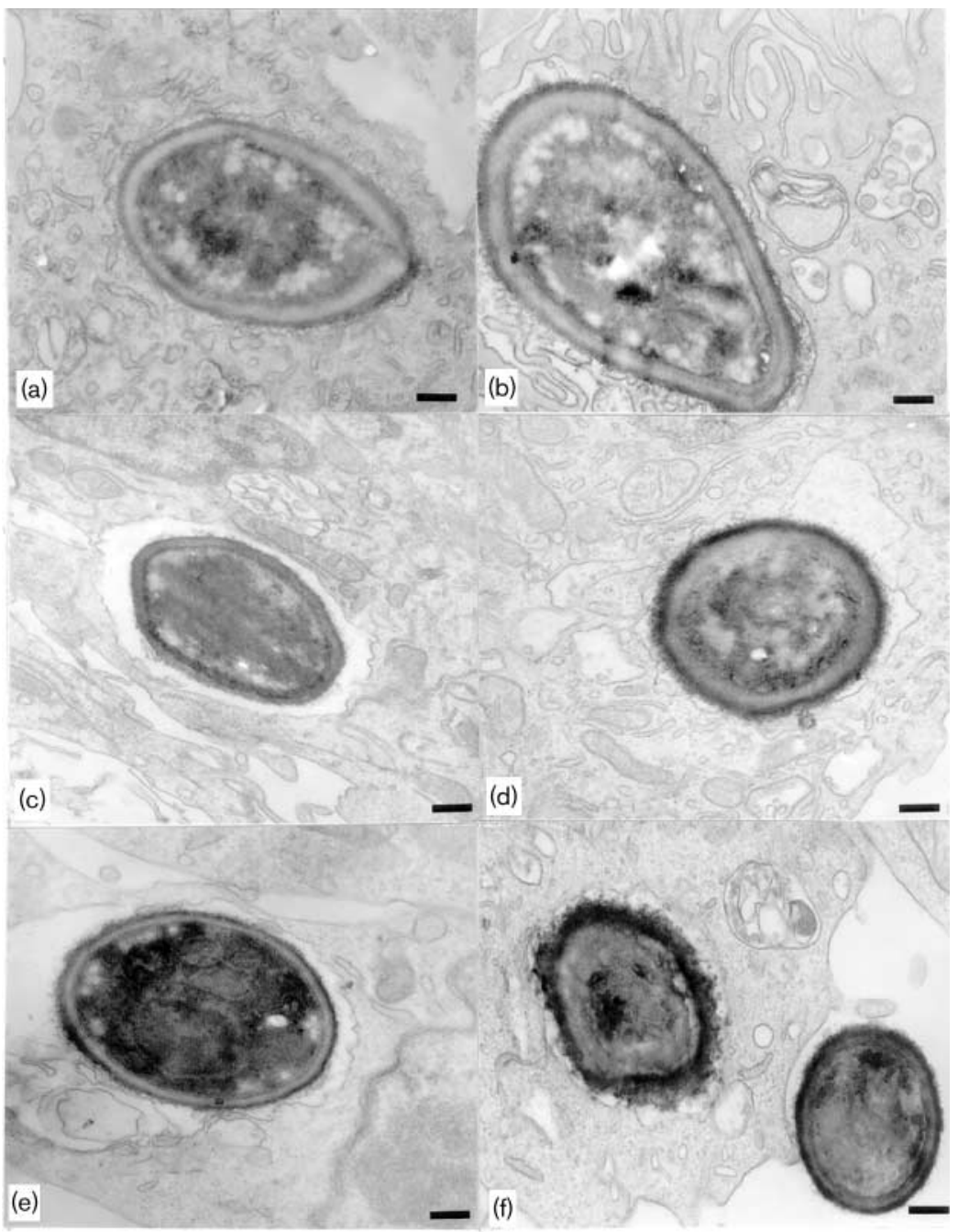

Fig. 7. Transmission electron micrographs of the interaction of F. pedrosoi conidia and host cells after a $1 \mathrm{~h}$ interaction at $37{ }^{\circ} \mathrm{C}$. Control macrophages (a) show a 'tight' phagosome. Macrophages pre-treated with staurosporine (b), genistein (c) or calphostin C (d) for 30 min prior to the interaction present altered cellmembrane structures. The $\mathrm{CHO}$ control (e) and $\mathrm{CHO}$ cells pre-treated with calphostin ( $f$ ) presented a 'loose' phagosome. Bars, $0.35 \mu \mathrm{m}$.

natural shape and host cells did not show the emission of traditional pseudopods at the region of the initial contact with the fungus (Fig. 7f). CHO cells treated with genistein and staurosporine prior to the interaction showed effects similar to those observed with calphostin (data not shown).

\section{DISCUSSION}

Protein phosphorylation is generally accepted to play key roles in transducing signals involved in several processes such as cell adhesion, internalization and killing of pathogens (Reiner, 1994). Pharmacological agents that arrest invasion at a specific step are useful experimental tools that can provide clues about what is going on biochemically within the cell and the parasite as it attaches and enters the cell (Ward et al., 1994). Inhibitors of enzyme activity are valuable tools for probing kinase/phosphatase involvement in cellular processes; however, as the use of such compounds has inherent limitations due to non-specific reactions, it is important to bear in mind the properties of these compounds. Especially crucial is whether the inhibitor binds directly to the PK and with what affinity, how specific it is for a given kinase and how permeable the fungal cell is to a given inhibitor (Finlay et al., 1989). In this study, we used the PK inhibitors staurosporine, genistein and calphostin $\mathrm{C}$ to analyse the roles played by the PK activities of $F$. pedrosoi conidia and host cells in the interaction process. The inhibitors employed here presumably down-regulated cell PK activity, as treatments were performed prior to infection. We have shown here that pre-treatment of macrophages, epithelial cells and conidia with PK inhibitors decreased conidium invasion and that this could be overcome with okadaic acid in most cases. Our results suggest that not only is the mammalian cell PK activity important in the interaction process, but also that protein phosphorylation that occurs within the conidia may play a significant role in invasion.

Staurosporine is a potent inhibitor of several different Ser/ Thr kinase classes, including PKC and cAMP-dependent PK and some PTKs (Tamaoki, 1991). Staurosporine inhibited the conidium adhesion and invasion processes in macrophages, suggesting that PKs are necessary for both steps. However, in the case of epithelial cells, only the invasion process was arrested. Similar results were obtained with genistein and calphostin C. It is important to point out another important difference between the response of 
epithelial cells and macrophages to the drugs used here: when conidia were pre-treated with the drugs, no effects were observed on the interaction with macrophages. On the contrary, invasion of epithelial cells by the fungus was strongly inhibited. These results suggest that, in the case of phagocytic cells, the PK machinery of the fungus is not necessary for its entry, but, for non-phagocytic cells, the fungus has to use its own PKs to facilitate invasion of the cell, suggesting a truly active process of penetration.

It is intriguing to note that staurosporine blocks invasion in epithelial cells at a step that is morphologically similar to the arrest seen when the cells are treated with cytochalasins (Farbiarz et al., 1992). In both cases, the early stages of invasion (recognition and adhesion) appear to proceed normally, but the attached fungi are not internalized. Cytochalasin D binds to the barbed end of actin filaments and is a specific inhibitor of actin-based processes in intact cells (Ohmori et al., 1992). Entry of a particle into a cell by phagocytosis requires reorganization of the actin-based cytoskeleton underlying the region of the plasma membrane that contacts the particle. F-actin assembly in this region is initiated by signals that arise from the interaction of phagocytosis-promoting receptors on the cell surface with ligands on the surface of the particle (Greenberg, 1995). Farbiarz et al. (1992) have suggested the existence of two mechanisms used by F. pedrosoi to penetrate vertebrate cells. One is a typical phagocytic process, with formation of pseudopods. The second occurs even in the absence of actin filaments and is probably the same mechanism used to infect epithelial cells, in a process in which the fungus may play an active role (Farbiarz et al., 1992).

The potential involvement of PTKs in regulating the interaction was verified by the use of genistein. In this study, we showed that this PTK inhibitor could also block fungus internalization after treatment of mammalian cells. Genistein inhibits the binding of ATP to the enzyme (Akiyama $e t$ al., 1987; Yaish et al., 1988) and is a highly specific PTK inhibitor; it exhibits a weak inhibitory effect against proteinSer/Thr kinases and scarcely inhibits cAMP-dependent PK activity (Akiyama \& Ogawara, 1991). Genistein treatment of the fungus did not interfere with the interaction with macrophages, but inhibited interaction with epithelial cells, suggesting that fungal PTK participates in entry into epithelial cells. This observation suggests the existence of tyrosine kinases in F. pedrosoi, in contrast with the idea that no tyrosine kinases exist in filamentous fungi and that Ser/Thr kinases represent virtually all of the PKs found in these fungi (Dickman \& Yarden, 1999).

$\mathrm{PKC}$ is a protein-Ser/Thr kinase involved in the regulation of many cellular processes, including cellular growth, differentiation and tumour promotion (Nishizuka, 1986). To examine whether PKC activity is needed for invasion by $F$. pedrosoi, we tested the effect of an inhibitor that is known to have a higher specificity for PKC. Staurosporine inhibits the proteolytically generated catalytic domain of PKC, while calphostin $\mathrm{C}$ interacts with the regulatory domain, being a highly specific PKC inhibitor (Tamaoki, 1991). Previous incubation of the host cells with calphostin $\mathrm{C}$ blocked fungal invasion. This effect was especially evident in $\mathrm{CHO}$ cells. The same effect was observed when conidia were pre-treated and allowed to interact with the cells. Calphostin C seems to be the only kinase antagonist that caused some effect on the adhesion of conidia to epithelial cells, suggesting that cellular PKC may participate in the adhesion of the fungus to epithelial cells, while cellular PTK and PKC participate in the adhesion of $F$. pedrosoi to macrophages.

Since the effects of PK inhibitors are, in most cases, alleviated by okadaic acid in a dose-dependent manner, and since okadaic acid is a specific inhibitor of protein-Ser/Thr phosphatases 1 and $2 \mathrm{~A}$, with little effect on protein-tyrosine phosphatases (Cohen et al., 1990; Hardie et al., 1991), it seems likely that protein-Ser/Thr kinases within the host cells and the fungus are possible targets for staurosporine. Okadaic acid reversed the effect of staurosporine in all the cells tested, as well as the effect of genistein and calphostin C in macrophages.

Káposzta et al. (1999) have shown that PKC activity is essential for phagocytosis of Candida. The inhibitory effect of staurosporine on internalization of Candida albicans by macrophages reflects the role of PKC in actin polymerization and in recruitment of cytoskeletal proteins to the binding sites of particles (Allen \& Aderem, 1995, 1996). In addition, a tyrosine kinase was involved in tumour necrosis factor $\alpha$ production by macrophages after stimulation by C. albicans (Jouault et al., 1998). Shahan et al. (2000) demonstrated that fungal spores from different species activate macrophages differentially, especially by PTK activation. Pathogen invasion has recently sparked great interest, not only because its study may lead to better ways of controlling important pathogens but also because it may help to understand fundamental aspects of cell biology (Pace et al., 1993).

Immunofluorescence assays using monoclonal anti-phosphotyrosine antibodies revealed an accumulation of tyrosine-phosphorylated residues at the site of fungus attachment on the macrophage surface, although no labelling was observed after parasite internalization. It may be inferred that tyrosine phosphorylation during this process is an early, local and short-lived event. Simultaneous labelling of the cells with phalloidin showed that actin filaments also participate in this process. This is consistent with the transient nature of most PTK-mediated responses (Ulrich \& Schlessinger, 1990). Phosphoserine staining was observed in macrophage phagocytic vacuoles containing fungi. This observation suggests a later and longer phenomenon, where protein-Ser kinases participate in the phagocytosis process itself. The fact that phosphothreonine staining was weaker, in fact almost indiscernible, does not exclude participation of protein-Thr kinases in the interaction process. Protein-Thr kinase activation could be a transient event, difficult to detect by the approach used in the present study.

Our observations by transmission electron microscopy showed that conidia infect macrophages by a typical phago- 
cytic process, with formation of pseudopods and a 'tight' phagosome. When the cells were pre-treated with PK inhibitors, no pseudopods were observed and the ingested fungi where found in a 'loose' type of phagosome vacuole, similar to that found in epithelial cells and in cytochalasintreated macrophages, thus indicating a process of interaction in which the fungus plays an active role.

The study of kinases and phosphatases in pathogenic fungi has become an active area of research in biology. The present results demonstrate that signal-transduction networks involving PK and protein phosphatase activities can modulate crucial events during $F$. pedrosoi infection.

\section{ACKNOWLEDGEMENTS}

The authors thank A. Bosco and M. C. Costa for technical assistance. This work was supported by Fundação Universitária José Bonifácio (FUJB), Conselho Nacional de Desenvolvimento Científico e Tecnológico (CNPq), Fundação Carlos Chagas Filho de Amparo a Pesquisa do Estado do Rio de Janeiro (FAPERJ) and by Programa de Apoio a Núcleos de Excelência (PRONEX).

\section{REFERENCES}

Akiyama, T. \& Ogawara, H. (1991). Use and specificity of genistein as inhibitor of protein-tyrosine kinases. Methods Enzymol 201, 362-370.

Akiyama, T., Ishida, J., Nakagawa, S., Ogawara, H., Watanabe, S., Itoh, N., Shibuya, M. \& Fukami, Y. (1987). Genistein, a specific inhibitor of tyrosine-specific protein kinases. J Biol Chem 262, 5592-5595.

Allen, L. A. H. \& Aderem, A. (1995). A role for MARCKS, the $\alpha$ isozyme of protein kinase $\mathrm{C}$ and myosin $\mathrm{I}$ in zymosan phagocytosis by macrophages. J Exp Med 182, 829-840.

Allen, L. A. H. \& Aderem, A. (1996). Molecular definition of distinct cytoskeletal structures involved in complement- and Fc receptormediated phagocytosis in macrophages. J Exp Med 184, 627-637.

Casadevall, A. (1995). Antibody immunity and invasive fungal infections. Infect Immun 63, 4211-4218.

Clerc, P. \& Sansonetti, P. J. (1987). Entry of Shigella flexneri into HeLa cells: evidence for directed phagocytosis involving actin polymerization and myosin accumulation. Infect Immun 55, 2681-2688.

Cohen, P., Holmes, C. F. B. \& Tsukitani, Y. (1990). Okadaic acid: a new probe for the study of cellular regulation. Trends Biochem Sci 15, 98-102.

Courtneidge, S. A. (1994). Protein tyrosine kinases, with emphasis on the Src family. Semin Cancer Biol 5, 239-246.

Dickman, M. B. \& Yarden, O. (1999). Serine/threonine protein kinases and phosphatases in filamentous fungi. Fungal Genet Biol 26, 99-117.

Falkow, S. (1991). Bacterial entry into eukaryotic cells. Cell 65, 1099-1102.

Farbiarz, S. R., De Carvalho, T. U., Alviano, C. \& De Souza, W. (1990). Fine structure and cytochemistry of the interaction between Fonsecaea pedrosoi and mouse resident macrophages. J Med Vet Mycol 28, $373-383$

Farbiarz, S. R., De Carvalho, T. U., Alviano, C. \& De Souza, W. (1992). Inhibitory effect of melanin on the interaction of Fonsecaea pedrosoi with mammalian cells in vitro. J Med Vet Mycol 30, 265-273.

Finlay, B. B. \& Falkow, S. (1988). Comparison of the invasion strategies used by Salmonella cholerae-suis, Shigella flexneri and Yersinia enter- ocolitica to enter cultured animal cells: endosome acidification is not required for bacterial invasion or intracellular replication. Biochimie $\mathbf{7 0}$, 1089-1099.

Finlay, B. B., Fry, J., Rock, E. P. \& Falkow, S. (1989). Passage of Salmonella through polarized epithelial cells: role of the host and bacterium. J Cell Sci Suppl 11, 99-107.

Greenberg, S. (1995). Signal transduction of phagocytosis. Trends Cell Biol 5, 93-99.

Hardie, D. G., Haystead, T. A. J. \& Sim, A. T. R. (1991). Use of okadaic acid to inhibit protein phosphatases in intact cells. Methods Enzymol 201, 469-476.

Hunter, T. (1995). Protein kinases and phosphatases: the Yin and Yang of protein phosphorylation and signaling. Cell 80, 225-236.

Isberg, R. R. (1991). Discrimination between intracellular uptake and surface adhesion of bacterial pathogens. Science 252, 934-938.

Isberg, R. R. \& Tran Van Nhieu, G. (1994). Binding and internalization of microorganisms by integrin receptors. Trends Microbiol 2, 10-14.

Jarvis, W. D., Turner, A. J., Povirk, L. F., Traylor, R. S. \& Grant, S. (1994). Induction of apoptotic DNA fragmentation and cell death in HL-60 human promyelocytic leukemia cells by pharmacological inhibitors of protein kinase C. Cancer Res 54, 1707-1714.

Jouault, T., Fradin, C., Trinel, P. A., Bernigaud, A. \& Poulain, D. (1998). Early signal transduction induced by Candida albicans in macrophages through shedding of a glycolipid. J Infect Dis 178, 792-802.

Káposzta, R., Maródi, L., Hollinshead, M., Gordon, S. \& Da Silva, R. P. (1999). Rapid recruitment of late endosomes and lysosomes in mouse macrophages ingesting Candida albicans. J Cell Sci 112, 3237-3248.

Levitz, S. M. (1992). Overview of host defenses in fungal infections. Clin Infect Dis 14 (Suppl. 1), S37-S42.

Limongi, C. L., Rozental, S., Alviano, C. S. \& De Souza, W. (1997). The influence of surface carbohydrates on the interaction of Fonsecaea pedrosoi with Chinese hamster ovary glycosylation mutant cells. Mycopathologia 138, 127-135.

Limongi, C. L., Alviano, C. S., De Souza, W. \& Rozental, S. (2001). Isolation and partial characterization of an adhesin from Fonsecaea pedrosoi. Med Mycol 39, 429-437.

McGinnis, M. R. (1983). Chromoblastomycosis and phaeohyphomycosis: new concepts, diagnosis, and mycology. J Am Acad Dermatol 8, $1-16$.

Moulder, J. W. (1985). Comparative biology of intracellular parasitism. Microbiol Rev 49, 298-337.

Nishizuka, Y. (1986). Studies and perspectives of protein kinase C. Science 233, 305-312.

Ohmori, H., Toyama, S. \& Toyama, S. (1992). Direct proof that the primary site of action of cytochalasin on cell motility processes is actin. J Cell Biol 116, 933-941.

Oliveira, L. G., Resende, M. A., Lopes, C. F. \& Cisalpino, E. O. (1973). Isolamento e identificação dos agentes da cromomicose em Belo Horizonte. Rev Soc Bras Med Trop 7, 1 (in Portuguese).

Pace, J., Hayman, M. J. \& Galán, J. E. (1993). Signal transduction and invasion of epithelial cells by $S$. typhimurium. Cell 72, 505-514.

Reiner, N. E. (1994). Altered cell signaling and mononuclear phagocyte deactivation during intracellular infection. Immunol Today 15, 374-381.

Rippon, J. W. (1988). Chromoblastomycosis. In Medical Mycology, pp. 278-296. Edited by W. B. Saunders. Philadelphia: Harcourt Brace.

Rosenshine, I., Duronio, V. \& Finlay, B. B. (1992). Tyrosine protein kinase inhibitors block invasin-promoted bacterial uptake by epithelial cells. Infect Immun 60, 2211-2217. 
Rozental, S., Alviano, C. S. \& De Souza, W. (1994). The in vitro susceptibility of Fonsecaea pedrosoi to activated macrophages. Mycopathologia 126, 85-91.

Shahan, T. A., Sorenson, W. G., Simpson, J., Kefalides, N. A. \& Lewis, D. M. (2000). Tyrosine kinase activation in response to fungal spores is primarily dependent on endogenous reactive oxygen production in macrophages. J Biol Chem 275, 10175-10181.

Tamaoki, T. (1991). Use and specificity of staurosporine, UCN-01, and calphostin $\mathrm{C}$ as protein kinase inhibitors. Methods Enzymol 201, 340-347.

Ulrich, A. \& Schlessinger, J. (1990). Signal transduction by receptors with tyrosine kinase activity. Cell 61, 203-212.
Van der Geer, P., Hunter, T. \& Lindberg, R. A. (1994). Receptor proteintyrosine kinases and their signal transduction pathways. Annu Rev Cell Biol 10, 251-337.

Vieira, M. C. F., De Carvalho, T. U. \& De Souza, W. (1994). Effect of protein kinase inhibitors on the invasion process of macrophages by Trypanosoma cruzi. Biochem Biophys Res Commun 203, 967-971.

Ward, G. E., Fujioka, H., Aikawa, M. \& Miller, L. H. (1994). Staurosporine inhibits invasion of erythrocytes by malarial merozoites. Exp Parasitol 79, 480-487.

Yaish, P., Gazit, A., Gilon, C. \& Levitzki, A. (1988). Blocking of EGFdependent cell proliferation by EGF receptor kinase inhibitors. Science 242, 933-935. 